\title{
The Use of Podcast to Improve Students' Listening and Speaking Skillsfor EFL Learners
}

\author{
Ramli \\ Bosowa University, Makassar \\ English Education Program \\ asnandaramli@yahoo.com
}

\begin{abstract}
This study investigated the use of podcast to develop students' English skills, listening and speaking. Technology has produced prominent contribution on education in this information age. It is well known as edutechnology. Podcast is one of interactive medias applied to support learning process in the classroom in developing listening and speaking skills. This study reviewed some previous researchs and designed teaching instructions using Podcast. The result found that the potential achievement in using technology affected both students and teachers. Students motivately engaged themselves to sharpen their English achievements; listening and speaking with technology experiences. They obtained various instructions and interesting learning atmosphere. Besides, the teacher was also challenged to have an ability to integrate technology tools (such as Podcast) to perform a creative instruction in classroom setting. Podcast provided tremendeous topics and activities which make teachers and students enrich their knowledge as well as mastery their skills in educational purposes.

Keywords-Edutechnology, Podcast, Listening and Speaking Skills
\end{abstract}

\section{INTRODUCTION}

In the 21 st century, the development in computers, communication and Multimedia have changed the classrooms into Smart rooms in rapid. Teachers are expected to become The TechnoTeachers. Nowdays teachers face a big challenge to create a dynamic asmorphere and bring the world in the classroom activities.Technological phase of learning is needed as the part of English learning styles to change the traditional language rules [1].The growing numbers of English Language Learners make the search for new effective and efficient instructional methods, a priority, while several teaching methods and tools are used to help ELLs succeed in becoming proficient English speakers.Learners are highly relational and demand quick access to new knowledge and connect the world in this 21 st century. Learners also are capable of engaging in learning at a whole new level. With the world literally at their fingertips, today's students need teachers and administrators to re-envision the role of technology in the classroom [2] The use of technology to enhance the learning experiences of Students was investigated [3]. The purpose of this study is to investigate how technology tools helped ELLs become more proficient in English. The theorie of second language acquisition will be used to make a better understanding in how [4] comprehensive the input theory being delivered using new technology provides learners with comprehensible materials leading to acquire the language faster. He also explains using technology tools as a way of enhancing ELLs languageacquisition by providing a rich and comprehensive input that will be relevant in motivating ELLs.

\section{Technology and English Teaching}

In listening comprehension, the second or the foreign language listening has been relatively ignored for many years, within the applied of linguistics, today has came into its own. Although still, somewhat neglected in the second language acquisition's researchs, listening, now plays a more central role in language teaching, and speaking is the outcome of the listening process. [5] stated that listening provides the listeners information from which to develop their knowledge. When this knowledge is being developed, students will begin to speak, so listening has a crucial role in communication [6] [7].Recently, many tests like theentrance exams, university leaving tests and others have begun to include the listening comprehension components, and acknowledgment that listening and speaking abilities are important aspects of language proficiency. [8].

In this day of communication, besides speaking teaching, it is a vital importance that the students are taught to listen effectively and critically.In order to develop the students' speaking skills, listening is fundamental in the language classroom because it provides inputs for the learners. [9] stated, having week listening comprehension can be the factor in affecting the misunderstandings.Language learners often face many problems when they first attempt to listen to a new language. Although the problems are many and 
various, they are not all experienced by all students, nor they are experienced to the same degree by students from different backgrounds.

Reference [10] believes that the difficulties of listening for the EFL learners arise from seven main reasons: Speed, Repetition, Vocabulary, Signals, Interpretation, Concentration and Perfectionism. The learners need a great deal of exposure to spoken language and sufficient practice in various listening situations to develop their listening abilities. However, in addition to exposure and practice, it is important for the listeners to be engaged in the process of listening and develop their desires of understanding.Reference[11] Both listening and speaking become thebasic elements of the new standards for functional English. However, it appears significant lack of materialsfound to help the teachers to develop their learners' skills and this is the principal reason for producing more effective teaching procedures. When teaching listening and speaking are delivered well, it will provide the rich resources to make it explicit, relevant and engaging for thestudents.

However, current technology has paved the way for new faces of literacy proficiency such as being able to communicate with people from around the world (global literacy), interpret digital and nonlinear text (digital literacy) and designing, viewing and interpreting visual representations (Visual literacy) Reference [12]. If teachers continue to ignore the importance that the technology has in students' lives, the gap between home and school life will continue to widen and students will come to feel that their culture is not valued in the school setting. Already, the widening gap in home and school technology use has teachers taking notice of student disengagement in classReference[13]. Moreover, if educators continue to shy away from technology used in school, they are detrimentally affecting their student's futures. If technology use in schools is absent, students will be denied in accessing new literacy skills that are needed to navigate the growth of digitally mediated social practices in which employers are searching out and will continue to search for in the future. Fortunately, it is not too late for educators to realize the importance that the technology serves in the classroom setting. Technology can be incorporated into the classroom in a variety of ways to serve variety of purposes. Podcasting offers teachers one outlet for technology integration.By reviewing the challenges of teaching listening and speaking, podcast as one familiar technology becomes one interesting and innovative media to help learners improve their skills. Podcasting refers to the authoring of or subscription to audio and or video files that can be downloaded and played back on a wide range of mobile devices such as MP3 players and iPods Reference [14].

\section{Podcast to Improve Teaching and Learning}

This present study spesifies he use os Podcast as a part of technology.Reference[15] defines podcast asaudio and video contents on web as the series of episodes with a common theme. These episodes are accompanied by a file called a "feed" that allows listeners to subscribe to the series and receive new episodes automatically. It seems to be the new wing of change. The technology for podcast is readily available, easy to use and inexpensive, making it an attractive option for providing additional flexible learning resources for students.

Podcast was originally for conveying informationand entertainment. But soon educators saw the huge potential it has for teaching andlearningreference([16]; [17]). So the use of podcast is revolutionizing the English learning process.It emergenciallyappears to offer rich sources of materiasl to use in an EFL context and to assist foreign language instruction in general. Podcasts enable the students to choose when and where to learn and to do so at their desired learning pace and path. Moreover, podcasts can be easily downloaded, shared, and even edited, granting learners more control and ownership of their learning.

Given the flexibility to adopt and adapt, podcasts according to individual needs, students are generally more engaged in the learning process and learning outcomes are thus believed to be maximized.However, little is known about how podcasts are used by students and the implications for learning. Podcasts are a fantastic way for students to learn.Students can listen topodcastwhenever and whereverthey want.They don't have any visual clues. Studentscan find a podcast that interests them. To podcast about subjects which are interesting, relevant and useful for them will improve their inputs and motivations.In developing a taxonomy of podcasting for language learning,reference[18] identified two major uses: creating podcasts and using the available ones.

Some researchers have investigated the effectiveness of podcast to develop English proficiency. For example,reference[19]concerned with the effects of podcastson students' language skills and the second theme included learners' attitudes and perceptions toward podcasts. They found out that using podcast is more beneficial and helpful than using the traditional chalk andtalk method. Moreover, the integration of podcastin learning can improveacademic performance, enhance motivation, and promote learning. It also can accelerate language learners' learning notjust in listening but also in other language areas such as pronunciation, vocabulary, grammar, speaking and otherrelated learning activities. Another study also emphasized the benefits of Podcast in enhancing language skillsreference [1]. The uncovered blend of technology and language learning has given a new foundation in the educationalworld to transform it into Tech-edu. Innovative mobile technologies like podcast can encourage learners to appreciateliterature. It would also provide benefits for learners in their over all 
developments thereby establishingthe emergence of a new era in the learning process.

Based on the previous research, it is concluded that podcast is an effective and efficient tool in helping ELLs become proficient in language skills such as listening and speaking. In my viewpoint, listening comprehension is basically a process of understanding what the speaker said. In order to improve the students' speaking skills, listening is essential in the language classroom because it provides input for the learners. Without understanding input at the right level, students cannot begin to speak. Thus, I explore the use of podcast in the teaching of listening and speaking skills.

From the review of literature, this study is undertaken to Introduce the students about podcast,taken from British Councilas interesting tool of leaning activites.Students are expected to be able to express their ideas about social /environmental condition.One of the major themes that emerges from my study is increasing the motivation to practice listening and speaking with the podcasts. This theme becomes evident when we implement some activities using podcast in the classroom. The study begins by having the participants listen to the three stages of instructional podcasts. Those activities are devided into three main instructions; pre listening, whilst listening, and post listening. Each activities has different procedures and students' activites.

\section{Listening and speaking instruction using podcast}

In this paper, the writer provides the listening and speaking instructions for university students using podcast program. The followings are given some examples in listening and speaking instructions which some are developed by the teacher and some are selected from some sources. The procedures will be devided into three before, during and after listening.

Aims: developing listening and speaking

Level: 50-60 minutes

Source: VOA podcast, Worksheet, and Pen Procedure

\section{PRE LISTENING}

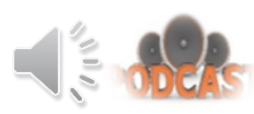

- Students will listen to the sound of "traffic jam" and the teacher asks the students.

- Where and when do they find the situation.

- What do they feel when they get in to traffic jam.

- What are students' strategies to avoid the traffic jam every day.

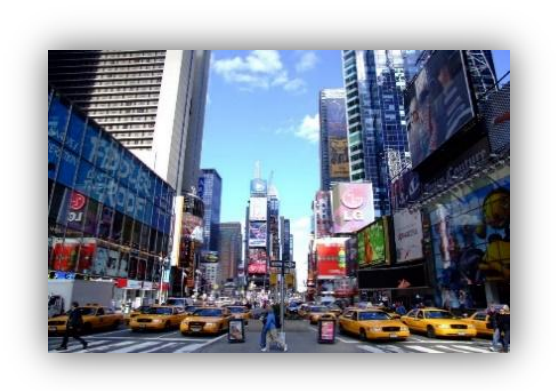

- The teacher shows picture about "City".

- The teacher asks what do the students see whether it is the view of a city or a countryside.

- The teacher asks where do the students prefer to live in "a city or a countryside".

- The teacher asks the students' experiences living in the city or in the countryside.

- The teacher gives few vocabularies about the content of the programme that they will listen.

- The teacher asks the students to predict what the speakers will talk about in the programme.

After giving a warming up about the lives of city, the teacher will remind the students to move to the next procedures with some activities.

\section{WHILST LISTENING INFORMATION GATHERING}

\section{LearnEnglish Professionals BRITISH COUNCIL \\ City Population}

Presenter: Hello and welcome to "Visions of the Future'. This week we're discussing about the growth of cities in the twenty first century. In the studio we have the environmentalist Sue Shaw and Masako Ito, an urban planner based in Tokyo. For the first time in the human history, more people now live in cities than in the countryside. Today Tokyo is the world's largest conurbation. The combined cities of the Tokyo Bay Area now have a population of 28 million. Masako, how has Tokyo solved the problem of transport? http://www.learnenglish.org.uk/prof_mp3/citypopulation

\section{Activities}

The students will listen to podcast. The topic is "City Population" with different activities (yes/no questions and comprehension questions).

Activity

$$
1
$$

Individual work: The teacher will introduce the speakers and their roles in the programme.

- Teacher distributes yes/no questions and ask the students to read before listening. 
Listen to this excerpt from a radio programme about living in a big city.

Optional activity: While you listen, decide whether the following sentences are true or false.

\begin{tabular}{|l|l|}
\hline Sentences & $\begin{array}{l}\text { True } \\
\text { False }\end{array}$ \\
\hline $\begin{array}{l}\text { 1. Sue Shaw is an expert on how to protect } \\
\text { the environment. }\end{array}$ & \\
\hline 2. Masako Ito lives in Tokyo. & \\
\hline $\begin{array}{l}\text { 3. Today the Tokyo Bay Area has a } \\
\text { population of 18 million. }\end{array}$ & \\
\hline $\begin{array}{l}\text { 4. New roads have solved Tokyo's transport } \\
\text { problems. }\end{array}$ & \\
\hline $\begin{array}{l}\text { 5. There are high charges for cars to use the } \\
\text { city's expressways. }\end{array}$ & \\
\hline 6. Travel by car is faster than travel by rail. & \\
\hline $\begin{array}{l}\text { 7. Tokyo's transport infrastructure is a useful } \\
\text { model for developing countries. }\end{array}$ & \\
\hline $\begin{array}{l}\text { 8. Cities in developing countries should not } \\
\text { rely on cars to solve their transport problems. }\end{array}$ & \\
\hline
\end{tabular}

- After listening, check the students' works and the number of students' correct answers

- Keeping students' motivation by reminding them about more challengging activities with comprehension questions.

Activity 2:

- In pairs work: The teacher distributes the comprehension questions and ask them to read the questions with their pairs first.

Relisten to this excerpt from a radio programme about living in a big city.

Optional activity: While you are listening, answer the following comprehension questions.

1. What does the programme talk about?

2. What is the requirement of a having car in Tokyo?

3. Why does she propose people in stopping the use of car as the meant of transport?

4. What is the environmental mentalist's propose to protect environment in mega city?

5. Do you agree about her solution of the transport problem?

After the first listening, the teacher asks the students whether the teacher needs to replay the audio or not. (Listening again). And at the end, the teacher invites them to share their opinions.
Activity:

After listening 20 minutes

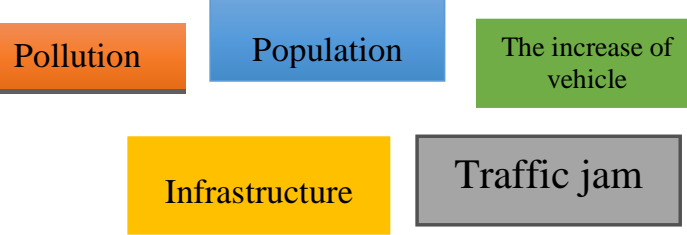

Discussion : In pairs, students are given different topics related to the city population. Then they exchange their ideas or opinions to discuss some issues in city environment and find the alternative solution in how to overcome the problems.

Follow-up Roleplay: After the discussion, students provide a list of questions they would like to ask: either about the topic of the programme, or to the person or people featured in the programme. Based on their pairs or groups: they take roles such as the presenter or the guest, the enviromentalist and ask and answer the questions. If they don't know the answers, they can use avoidance strategies or make something up regarding to the topics.

In the end of the class, the teacher will share some web sites providing podcasts such as VOA or $\mathrm{BBC}$ and allow the students to download them based on their interest so they can learn everytime and everywhere to improve their English proficiencies.

\section{Podcast and The Outcomes of learning}

The results of this study showed that teaching listening and speaking using podcast createdsome activities and learning outcomes.In addition to viewing and listening to a podcast, students engage in the activity of listening practice with podcast for the purpose of exchanging ideas in relation to find the alternative solution in how to overcome transport problem in city environment. It is observed that students seem to be engaged in the task. Using podcasting as the meaning of supporting and providing a multimodal form of communication was another recurring theme that emerged from my data. Like me, reference [20] also found that podcasting can be used to tap into different literacies because of its multimodal communication approaches. A podcast can contain different components depend on the type of podcast being accessed. Some podcasts are completely audio- based, denying the viewer of any visual stimulation. Other podcasts provide users with a mixture of audio and visual texts, while other podcasts are a mixture of audio and still images. Depending on the type of podcast being utilized, different components of the technology may be more useful to individuals based on literacy preferences or predominant intelligences. As stated previously, participants viewed two types of podcasts. One

\section{POST LISTENING}

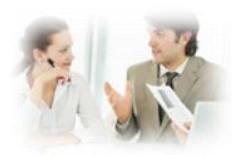


podcast appealed to one's audio sense and the others were more visually stimulating. In somestudies, participants seemed to be engaged while listening to podcast. Although both students seemed to prefer the podcast because of the visual elements, it is possible that the students who are more auditory learners may have more benefites from the audio-based podcast as presented by reference [21]. Knowing that students learn in many different ways, podcasting offers a way for teachers to deliver instructions that appeal to the auditory and visual learners.

The findings of my research suggest several implications for the role of teachers. Podcasting is a technology that could and should be used with a wide spectrum of students, ranging from the primary grades to adult learners. Teachers can use the avalaible one or the mobility of podcastthat offers users flexibility in obtaining, creating and distributing the podcast files. Podcasting, when it is integrated into the teacher's instruction, lends itself to be an engaging method of instructional delivery. Teacher also develop their abilities to operate the update technology like podcast and have accessibility to practice the students' listening comprehensions and lastly, when it is used meaningfully, podcasting can promote collaboration and authentic learning experiences. One benefit of podcasting is that it is a mobile learning tool.

However, the same instruction tools accessed from a home computer could be used on a school computer or library computer and so on. To allow for a greater mobility, a podcast accessed from a computer could be downloaded to an MP3 player and listened to while on the go. Teachers could provide their students with lecture's notes, homework examples and enrichment opportunities in the form of a podcast. Another benefit of podcasting is that it provides students with an engaging outlet of instruction. Students can be exposed to a variety of different podcasts that stimulate different senses while still engaging in meaningful learning tasks. Interweaving technology and instruction will help to close the gap between the literacy experiences students are taking in at home and what they are engaging in schoolreference[22]. Moreover, students' engagements can increase when the students take a part in building their own podcast. The authenticity of work is also recognized when podcasts are viewed by real audiences, such as in the peer revising lesson. Students' collaborations can also be achieved through the use of podcasting. As seen in this study, after gathering a particular information (problem transport in city) from podcast, collaboration can take the form of two students working collaboratively to share information and exchange their ideas and perspectives about the spesific issues, but it do not need to stop there. Classrooms can communicate with other classrooms within the same school, community or state. There is even a possibility of students becoming podcasting pen pals with students in other friends from other countries, much like what was seen in the research of reference [23] where the American students communicated with Spanish students via podcast to discuss issues that affecting teens. In this way, podcasting extends the possibilities for teachers to incorporate global literacy in their classrooms. As one can see, there are many reasons why teachers should consider incorporating podcasting into their instructions.

From the study it is believed that the influences of using podcast in English language skills such as listening and speaking contribute a lot to give some improvements both for the teachers and the students. Teacher can bring ICT into the classroom, in the same time teacher is able to improve their technology skilsl in other to create the teaching atmosphere in the $21 \mathrm{st}$ century. For students, podcast provides students' learning styles, they might change their ways to practice listening, increase vocabulary level, grammatical sentence, intonation, and imitate pronunciation. Those activities directly raise their motivation and willingness to apply their learning styles because it is more interesting and flexible to study. While students improve their language competences, they can also focus on the input. The more students listen various topics from podcast based on their interest, the more they store rich ideas and information that might be very important sources in performing speaking and even in writing.

By having repertoires of classroom's activites using podcast, it showed that the use of podcast in listening practices integrated with speaking can engage or involve the students to be active in some activities. It proves that podcasts can be used most effectively. Podcast has also been argued to lead to passive learning with students focussing on the audio facility rather than actively engaging with the lecture's contenst. The use of podcast depends on how this technology is put to use including goals and appropriate learning activities. Podcast does not contain any inherent value. It is only valuable inasmuch as it helps the teachers and the students reach their educational goals, by facilitating thoughtful, engaging learning activities that are designed to work in supportinthose goals.

\section{CONCLUSION}

We can not deny that technology in the $21 \mathrm{st}$ century takes an important role in developing teaching instruction and learning styles of students in improving students' English skills, particularly in listening and speaking. What this study has explored that the use of podcast is very helpful to create classroom activities and students seem to be very motivated and attractive to engage themselves in listening and speaking practices in the classroom. The students enable to gather spesific informations from podcast and involve into group to use the information in order to discuss some alternative solutions about problems faced by the speakers in podcast. It showed 
that podcast brings various interesting topics that enable to enrich students' inputs. Using teachnology like podcast, the teacher is also able to design an appropriate instruction and develop hi or her skill in operating technology. From that reason, to become computer literate and to use technology tools to increase academic performance, teachers need to dedicate trainings and plans for the ongoing professional development. It is expected the role of technology i.e. podcast as tool of learning can help teachers and students reach the goals of education.

\section{REFERENCES}

[1] Rajval S. \& Devi V.A. (2011).Podcast: Enhancing Listening and Speaking Skills. Language in India. Strength for today and bright hope for tomorrow, 11: ISSN 1930-2940.

[2] Blair, N. 2012. Technology Integration for the New 21st Century Learner Today's students need educators to re-envision the role of technology in the classroom. PRINCIPAL:

Florida.

https://www.naesp.org/

[3] Diallo A., (2014). The Use of Technology to Enhance The Learning Experience of ESL Students. Concordia University: Portland

[4] Krashen, S. (1982). Principles and practice in second language acquisition. London: Pergamon Press.

[5] Jafari, Khadijeh \& Hashim, Fatimah. 2012. The effects of using advance organizers on improving EFL learners' listening comprehension: A mixed method study. System. 40; 270-281 doi: 10.1016/j.system.2012.04.009

[6] Nunan, I. S. P., \& Newton, J. 2009. Teaching ESL/EFL listening and speaking. New York: Routledge.

[7] Vandergrift, L. 2007. Recent developments in second and foreign language listening comprehension research. Language Teaching. 40; 191-210

[8] Richard Jack C. (2009). Teaching Listening and Speaking from the Theory to Practice. plenary address at the 2009 TESOL convention in denver USA.

[9] Fitch-Hauser, Margaret; Powers, William G.; O'Brien, Kelley; Hanson, Scott. (2007).Extending the Conceptualization of Listening Fidelity. International Journal of Listening, Vol. 21: 81-91
[10] Ur, Penny. (1984). Teaching Listening Comprehension. Cambridge: Cambridge University Press.

[11] Cole, Debbie, Christine Ellis, Barbara Mason, John Meed, Deborah Record, Anna Rossetti, Graham Willcocks. (2007). Teaching speaking and listening a toolkit for practitioners. Portishead Press: Bristol

[12] Cohen, V. L, \& Cowen, J.E. (2008). Literacy for children in an information age. Belmont: Thomson Wadsworth.

[13] Bauleke, D. \& Herrmann, K. (2010). Reaching the iBored. Middle School Journal, 41(3), 33- 38.

[14] Dale, C. \& Pymm, J. M. (2009). Podagogy: The iPod as a learning technology. Active Leaning In Higher Education, 10(1), 84-96.

[15] Deal, Ashley. (2007). Teaching with technology. Creative Commons Attribution-Noncommercial-No Derivative Works 3.0 United States License http://creativecommons.org/licenses/by-nc-nd/3.0/us/

[16] Warlick, D. (2005). Podcasting. Technology \& Learning, 26(2), 70-70.

[17] Adams, C. (2006). Geek's guide to teaching in the modern age.Instructor, 115(7),

48-51

[18] Rosell-Aguilar, F. (2007). Top of the pods - In search of a podcasting "podagogy" for language learning. Computer Assisted Language Learning, 20(5), 471-492.

[19] Hasan, Md. M. \&Hoon T. B. (2011). Podcast Applications in Language Learning: A Review of RecentStudies. English Language Teaching, 6 (2)ISSN 1916-4742 E-ISSN

19164750doi:10.5539/elt.v6n2p128

[20] Crawford, C. (2007). Podcasting and video integration into the learning environment.

International Journal of Learning, 13(9), 39-48.

[21] Gardner, H. (1999). Intellignece reframed:Multiple intelligence for the 21st century. New York: Basic Books.

[22] Davidson, C. (2009). Young children's engagement with digital texts and literacies in the home: Pressing matters for the teaching of english in the early years of schooling. English Teaching: Practice and Critique, 8(3), 36-54

[23] Lee, L. (2009). Promoting intercultural exchanges with blogs and podcasting: A study of spanish-american telecollaboration. Computer Assisted Language Learning, 22(5), 425-443. 